\title{
EXECUTIVE ORDER NO. 11,246 AS AN ALTERNATIVE TO TITLE VII: THE ELIMINATION OF DISCRIMINATION IN BONA FIDE SENIORITY SYSTEMS
}

As economic conditions have become less predictable and collective bargaining agreements have grown more sophisticated, workers' seniority provisions ${ }^{1}$ have emerged as crucial employment terms. Probably more than any other labor provision, seniority rights affect the economic security of individual employees. ${ }^{2}$ Hence, the incidence of unlawful discrimination in seniority agreements has increasingly commanded the attention of the courts, Congress and legal commentators. $^{3}$

However, the ability of the judiciary to relieve discrimination resulting from seniority agreements remains uncertain. ${ }^{4}$ Unquestionably, seniority provisions that are framed with an intent to discriminate on the basis of race, color, religion, sex or national origin are illegal under section 703(h) of Title VII of the Civil Rights Act of $1964 . .^{5}$ But the

THE FOLLOWING CITATIONS WILL BE USED IN THIS NOTE:

Speck, Enforcement of Nondiscrimination Requirements for Government Contract Work, 63 ColUM. L. REV. 243 (1963) [hereinafter cited as Speck];

Comment, The Philadelphia Plan: A Study in the Dynamics of Executive Power, 39 U. CHI. L. REv. 723 (1972) [hereinafter cited as Chicago Comment].

1. A "seniority system" may be defined as a set of rules governing job mobility in an em. ployment unit, including such features as promotion, demotion, transfer and layoff. For a more complete definition, see Note, Title VII, Seniority Discrimination, and the Incumbent Negro, 80 HARV. L. REv. 1260, 1263 (1967).

2. Collective bargaining agreements usually contain a "last hired, first fired" clause providing that employees with the least seniority be laid off first. See Note, Last Hired, First Fired Layoffs and Title VII, 88 HARV. L. Rev. 1544 (1975). Moreover, due to recent economic conditions, many employers who had only recently hired significant numbers of minority employees have been forced to lay off workers. See id. 1544. See generally Aaron, Reflections on the Legal Nature and Enforceability of Seniority Rights, 75 HARv. L. REv. 1532 (1962).

3. See, e.g., International Brotherhood of Teamsters v. United States, 431 U.S. 324 (1977); 42 U.S.C. § 2000e-2(h) (1976); Note, supra note 1.

4. Section 703(h) of Title VII (codified at 42 U.S.C. $\& 2000$ e-2(h) (1976)) and Executive Order No. 11,246, 3 C.F.R. 339 (1964-1965 Compilation), reprinted in 42 U.S.C. following \& 2000e (1976), create two variant standards. The statute allows "bona fide" seniority systems, while the order makes illegal any discrimination, regardless of the "bona fide" nature of the system.

5. Section 703(h) (codified at 42 U.S.C. $\$ 2000 \mathrm{e}-2(\mathrm{~h})(1976)$ ) provides in part:

Notwithstanding any other provision of this subchapter, it shall not be an unlawful employment practice for an employer to apply different standards of compensation, or different terms, conditions, or privileges of employment pursuant to a bona fide seniority or merit system, or a system which measures earnings by quantity or quality of production 
meaning of section 703(h) becomes more ambiguous in view of its declaration that "bona fide seniority systems" are not unlawful. ${ }^{6}$ Resolving a conflict in circuit court interpretations of this language, the Supreme Court in International Brotherhood of Teamsters v. United States ${ }^{7}$ finally established the scope of seniority rights under the Act: seniority agreements that are neutral on their face and in intent will not be struck down, in spite of any discriminatory effects. ${ }^{8}$ Moreover, the Court held that a system which tends to perpetuate pre-Act discrimination can still be "bona fide" and thus permissible under Title VII.

Notwithstanding the Teamsters decision, a new theory for relief from discriminatory employment terms, based upon Executive Order No. $11,246,{ }^{9}$ has recently been argued in the lower federal courts. ${ }^{10}$ The executive order demands that federal contractors and subcontractors take affirmative action to ensure that no employment discrimination exists in such areas as "upgrading, demotion, or transfer; . . . layoff or termination; rates of pay or other forms of compensation . . . "11 This controversial order has been widely used for many years to direct affirmative action programs by employers. ${ }^{12}$ Only recently, however, have the courts considered whether it may also be used to augment the relief provided under Title VII.

In United States v. East Texas Motor Freight System, Inc., ${ }^{13}$ the government argued before the Fifth Circuit that seniority provisions in union collective bargaining agreements violated Title VII of the Civil Rights Act as well as certain obligations imposed by Executive Order No. 11,246. The defendant company employed two types of truck-

or to employees who work in different locations, provided that such differences are not the result of an intention to discriminate because of race, color, religion, sex, or national origin ....

6. Id.

7. 431 U.S. 324 (1977). For a discussion of this case, see Young, Supreme Court Report, 63 A.B.A.J. 1126, 1126-28 (1977).

8. 431 U.S. at $349-50$.

9. 3 C.F.R. 340 (1964-1965 Compilation), reprinted in 42 U.S.C. following $\$ 2000 \mathrm{e}$ (1976).

10. See United States v. East Tex. Motor Freight Sys., Inc., 564 F.2d 179 (5th Cir. 1977). The court noted that the argument that "obligations on government contractors under the executive order are 'above and beyond' those imposed . . . by Title VII" was one never made until after the Teamsters decision. Id. at 185.

11. Exec. Order No. 11,246, § 202(a), 3 C.F.R. 340 (1964-1965 Compilation), reprinted in 42 U.S.C. following $\$ 2000 \mathrm{e}$ (1976). For a general overview of the order, see Lopatka, $A 1977$ Primer on the Federal Regulation of Employment Discrimination, 1977 U. ILL. L.F. 69, 121-25.

12. See, e.g., Southern Ill. Builders Ass'n v. Ogilvie, 471 F.2d 680, 685 (7th Cir. 1972) ("Affirmative action plans promulgated by the courts are part of the courts' power and duty to eliminate the vestiges of past discrimination"); Contractors Ass'n of E. Pa. v. Secretary of Labor, 442 F.2d 159 (3d Cir.), cert. denied, 404 U.S. 854 (1971) (holding the Philadelphia Plan, see note 59 infra, a constitutional exercise of presidential power).

13. 564 F.2d 179 (5th Cir. 1977). 
drivers: over-the-road (OTR) drivers, who drove between different cities, and city drivers, who were confined to one terminal. The government sued both the employer and the union, contending that minorities had been systematically excluded from the better and higher-paying OTR jobs. Furthermore, once an employee was allowed to transfer from a city to an OTR route he was prevented from carrying the seniority he had gained in his previous job to the OTR position. It was thus argued that the seniority provisions of the union agreements perpetuated the prior discrimination by discouraging transfers to the better jobs. ${ }^{14}$

The Fifth Circuit held, on the authority of Teamsters, that the agreement was bona fide under section 703(h), since the seniority provisions were neutral on their face. Deciding further that no relief could be granted for pre-Act discrimination, the court remanded the question of relief for post-Act discrimination to the district court. Dismissing the applicability of Executive Order No. 11,246, the circuit court held that the union was not a proper party under the executive order; that the executive order required that judicial proceedings against the union be brought under Title VII, which covers only "intentional post-Act" discrimination, and not under the order; and that the executive order lacked the force of law to the extent that it goes beyond the mandate of Title VII. ${ }^{15}$

The court's decision suggests a basic misreading of the background and intent of both the statute and the executive order. It ascribes clarity to the ambiguous legislative history of Title VII and disregards the strength of an executive order program that has been employed for almost forty years. Mistakenly, the court broadened the purview of the Act and narrowed that of the order, thus manufacturing an exclusive remedy which neither Congress, the courts nor the executive branch contemplated. This Note will focus upon the use of Executive Order No. 11,246 as a means of unfreezing the discriminatory effects of "bona fide" seniority systems. It will analyze the presidential authority to issue the order and the congressional acquiescence which allows such executive action. The Note will conclude that since congressional approval has been manifest, Executive Order No. 11,246 can provide an effective remedy reaching beyond Title VII.

14. Id. at 182 .

15. Id. at $184-85$. 


\section{EXECUTIVE ORDER No. 11,246}

\section{A. History and Scope.}

The executive order program prohibiting employment discrimination by government contractors has been in effect since World War II. ${ }^{16}$ In 1941, President Roosevelt issued Executive Order No. 8,802 ${ }^{17}$ which required the insertion of clauses barring employment discrimination by the contractor on the basis of race, creed, color or national origin into all defense contracts. A series of similar executive orders was issued during the presidential terms of Roosevelt and Truman, all based upon the executive's war powers. ${ }^{18}$ President Eisenhower's executive orders broadened the contract compliance programs and separated them from the President's power over defense production. ${ }^{19}$ Although originally the required clause only obligated a contractor to practice nondiscrimination, executive orders since 1961 have required a provision directing contractors to undertake "affirmative action" to ensure equal job opportunity. ${ }^{20}$ President Johnson's Executive Order No. 11,246 continued this affirmative action requirement and transferred compliance oversight to the Secretary of Labor. ${ }^{21}$

Since the federal government does business with virtually all major companies in the United States, the scope of Executive Order No.

16. In 1941, President Roosevelt issued Executive Order No. 8,802, 3 C.F.R. 957 (1938-1943 Compilation), which established the Fair Employment Practice Committee. Two years later, Executive Order No. 9,346, 3 C.F.R. 1280 (1938-1943 Compilation), expanded the powers of the Committee and directed that a broader nondiscrimination requirement be attached to all government contracts. See Hebert \& Reischel, Title VII and the Multiple Approaches to Eliminating Employment Discrimination, 46 N.Y.U. L. REv. 449, $451-52$ (1971). See generally Chicago Comment 725-26.

17. 3 C.F.R. 957 (1938-1943 Compilation).

18. See, e.g., Exec. Order No. 10,308, 3 C.F.R. 837 (1949-1953 Compilation) (creating the Committee of Government Contract Compliance). See generally Chicago Comment 725-26. The source of the President's war powers is article II, section 2, paragraph 1 of the Constitution, which makes the President commander-in-chief of the armed forces.

19. See Contractors Ass'n of E. Pa. v. Secretary of Labor, 442 F.2d 159 (3d Cir.), cert. denied, 404 U.S. 854 (1971). The court observed that in President Eisenhower's Executive Order 10,479, 3 C.F.R. 961 (1949-1953 Compilation), there was for the first time "no mention of defense production." 442 F.2d at 170. The order authorized the Committee on Government Contract Compliance to conduct activities not directly related to federal procurement.

20. President Kennedy's Executive Order No. 10,925, 3 C.F.R. 448 (1959-1963 Compilation), created the President's Committee on Equal Employment Opportunity and instituted a procedure whereby government contractors were to submit plans for the elimination of discrimination, including affirmative recruitment, hiring and promotion efforts. See Hebert \& Reischel, supra note 16, at 452-53. See generally Note, Executive Order 11246: Anti-Discrimination Obligations in Government Contracts, 44 N.Y.U. L. REV. 590 (1969).

21. 3 C.F.R. 339 (1964-1965 Compilation), reprinted in 42 U.S.C. following $\$ 2000$ e (1976). Prior to this executive order, compliance functions had been delegated to the President's Committee on Equal Employment Opportunity created during the Kennedy administration. See Note, supra note 20 , at 593 . 
11,246 is extensive. In 1971, it was estimated that the government expended $\$ 70$ billion annually in the procurement of its necessities. ${ }^{22}$ These government contracts involve approximately one-third of the country's work force. ${ }^{23}$ Executive orders have been justified as an appropriate exercise of the procurement power; one commentator suggests that the nondiscrimination clause is warranted by the tremendous value of government contracts, the large number of employees affected and the source of the funds used. ${ }^{24}$

\section{B. The Executive's Authority to Issue Executive Order No. 11,246.}

The chief executive's general authority to issue procurement rules flows from the mandate in article II, section 3 of the United States Constitution that "the President shall take care that the Laws be faithfully executed" and from article II, section 1, which provides that "executive power shall be vested in the President." Executive Order No. 11,246 implements section 205 of the Federal Property and Administrative Services Act of 1949.25 Congress, through section 205, explicitly granted the President authority "to prescribe such policies and directives . . . as he shall deem necessary to effectuate" 26 an "economical and efficient system for the procurement and supply"27 of government property and services. Courts have drawn from the authority of the procurement statutes the power of the executive "to achieve social and economic objectives only indirectly related to conventional procurement considerations."28 In Contractors Association of Eastern Penn-

22. Hebert \& Reischel, supra note 16 , at 455.

23. See Note, supra note 20, at 591-92.

24. Pasley, The Nondiscrimination Clause in Government Contracts, 43 VA. L. Rev. 837, 86667 (1957). The government justifies use of the clause by arguing that a policy of nondiscrimination will make more effective use of the work force by ensuring minority employment and that the government must set an example for contractors. Id. 867. Professor St. Antoine lends support to these positions, asserting that "the whole of our society should be enriched by the opening up of a vast new spectrum of job opportunities for large segments of the population that were previously excluded." St. Antoine, Affirmative Action: Hypocritical Euphemism or Noble Mandate?, 10 U. Mich. J.L. ReF. 28, 42 (1976).

25. 40 U.S.C. \& 486 (a) (1976).

26. $I d$.

27. $I d . \S 471$.

28. See Rossetti Contracting Co. v. Brennan, 508 F.2d 1039, 1045 n.18 (7th Cir. 1975). In Northeast Constr. Co. v. Romney, 485 F.2d 752 (D.C. Cir. 1973), the court stated:

Congress and the President have increasingly had recourse to the procurement power for nonprocurement objectives, as "a device for the accomplishment, implementation, or even formulation of important national policies and goals, as a sophisticated technique for public administration as well as procurement . . . . [sic] conditioning the award or the terms of government procurement contracts in order to promote national social or economic standards or goals that in themselves had no immediate relevance to supplying the particular procurement need." 
sylvania v. Secretary of Labor, ${ }^{29}$ the court noted that "it is in the interest of the United States in all procurement to see that its suppliers are not in the long run increasing its costs and delaying its programs by excluding from the labor pool available minority workmen."30 Other authorities point similarly to the notion that the antidiscrimination provisions of the executive order are related "to the establishment of 'an economical and efficient system for . . the procurement and supply' of property and services . . .."31 But despite the many cases supporting the nondiscrimination clause and holding that the executive order has the force and effect of law, if a provision of the order violates any expression of congressional intent-as in the area of discriminatory seniority terms-such a provision will not be sustained. ${ }^{32}$

The Supreme Court in Youngstown Sheet and Tube Co. v. Sawyer ${ }^{33}$ held that the President may not act in contravention of a stated legislative policy. ${ }^{34}$ The Court struck down as unconstitutional President Truman's executive order directing the Secretary of Commerce to seize and operate the nation's steel mills. Justice Jackson delineated the scope of executive power in his concurring opinion: when the President acts pursuant to an express or implied authorization of Congress, his authority is at a maximum; in the absence of either a grant or a denial of authority, the President can only rely upon his own independent powers; and when the President takes measures that are incompatible with the express or implied will of Congress, his power is at its lowest ebb. The second source of presidential power that Justice Jackson outlined is quite abstract and, hence, is the most difficult of the three to characterize and understand. Nevertheless, since many executive ac-

Id. at 760 (footnote omitted) (quoting Levanthal, Public Contracts and Administrative Law, 52 A.B.A.J. 35, 36-37 (1966)).

29. 442 F.2d 159 (3d Cir.), cert. denied, 404 U.S. 854 (1971).

30. 442 F.2d at 170 .

31. Farkas v. Texas Instrument, Inc., 375 F.2d 629, 632 n.1 (5th Cir.), cert. denied, 389 U.S. 977 (1967) (quoting 40 U.S.C.A. § 471); see Pasley, supra note 24, at 866-68. See generally Leventhal, supra note 28, at 35-38; see also Speck 248-49 and authorities cited therein ("several Presidents by executive order have prescribed use of procurement contract clauses to achieve other objectives," id. 248).

32. See Youngstown Sheet \& Tube Co. v. Sawyer, 343 U.S. 579 (1952); Weber v. Kaiser Aluminum \& Chem. Corp., 563 F.2d 216, 227 (5th Cir. 1977), cert. granted, 99 S.Ct. 720 (1979) ("executive orders may not override congressional expressions").

33. 343 U.S. 579 (1952). For a discussion of the Youngstown case, see 1 A. SutherLand, Statutes and Statutory Construction 226-27 (4th ed. C. Sands 1972).

34. 343 U.S. at 602 ; see id. at 635-38 (Jackson, J., concurring). Before this decision, the Court had interpreted article II, section 1 of the United States Constitution as vesting an almost unbounded set of "inherent" powers in the President. See Myers v. United States, 272 U.S. 52 (1926).

35. 343 U.S. at 635-38 (Jackson, J., concurring). 
tions are carried out in the absence of congressional authorization, it is a power source crucial to the executive function. ${ }^{36}$

Justice Jackson characterized this second area as a "zone of twilight" where both Congress and the President may possess concurrent authority. ${ }^{37}$ Under such circumstances, "Congressional inertia, indifference, or quiescence may . . . enable [or] . . . invite measures on independent presidential responsibility." ${ }^{38}$ The "independent powers" Justice Jackson referred to in his second category are more the product of passive congressional acceptance than the subject of constitutional or statutory delegation. Still, the Jackson opinion only speaks to the legitimacy, not to the initial source, of the power exercised. Where, then, lies the origin of the executive authority before congressional acquiescence?

Two theories may be advanced to explain how an otherwise undelegated executive power comes into being. One possibility is that reference to "independent powers" in Justice Jackson's second category may imply that the executive power vested in the President by article II, section 1 of the Constitution represents an affirmative delegation of some pervasive independent power, not at all statutorily based, and thus not subject to congressional invalidation. ${ }^{39}$ In such a case, the authority of the executive to issue the executive order would be unquestioned. ${ }^{40}$

Alternatively, the executive power in this area, although constitutionally based, may be "elastic" in that it can expand where the President in the exercise of his executive function needs to fill a void left by congressional inaction. ${ }^{41}$ However, this power must correspondingly contract when Congress has exercised its authority in the area or expressed a contrary intent. ${ }^{42}$ This view comports with Justice Frank-

36. Very few cases have been decided in this area. As one commentator observed shortly after the Youngstown decision, "[n]early every case concerning executive encroachment [of legislative powers] has involved an unconstitutional delegation of power, not an outright usurpation." Note, The Sleel Seizure Cases, 41 GEo. L.J. 45, 62 (1952).

37. 343 U.S. at 637 (Jackson, J., concurring).

38. Id.

39. See Note, Executive Orders and the Development of Presidential Power, 17 VILL. L. REv. 688, 694 (1972). See also Speck 244.

40. See Note, supra note 39, at 711 (whenever a President claims to act under his independent powers "the Supreme Court has been very reluctant to limit or invalidate such action").

41. See Speck 245; Note, supra note 39, at 699-701.

42. As one commentator contends in reference to Youngstown, "[i]n the most significant case striking down a presidential exercise of power, the Court indicated that it may have upheld the exercise had it not been for the previously expressed congressional disfavor toward such action." Note, supra note 39, at 711-12; see Youngstown, 343 U.S. at 602 (Frankfurter, J., concurring). For a practical example of the executive's "elastic" authority, see Speck 245 ("it can be said that the President in ordering a nondiscrimination clause is acting neither pursuant to an express or im- 


\section{furter's observations in Youngstown:}

In short, a systematic, unbroken, executive practice, long pursued to the knowledge of the Congress and never before questioned, engaged in by Presidents . . . making as it were such exercise of power part of the structure of our government, may be treated as a gloss on "executive power" vested in the President by $\S 1$ of Article II. ${ }^{43}$

Hence, an executive order may be promulgated without specific legal authority to do so, but may become sanctioned by the very fact that Congress did not invalidate it. ${ }^{44}$

United States v. Midwest Oil, ${ }^{45}$ a case decided before Youngstown, illustrates this concept of implied executive authority. ${ }^{46}$ There, although no statute explicitly authorized President Taft's action, ${ }^{47}$ the Supreme Court upheld his withdrawal of a large tract of land from public entry because such withdrawals had been undertaken for the previous eighty years with no congressional attempt to repudiate the assertion of presidential power. ${ }^{48}$ This lengthy period of legislative acquiescence served "as a gloss on 'executive power' vested in the President by $\S 1$ of Art. II." ${ }^{\text {.49 }}$ It is uncertain whether the outcome would have been the same had the practice been challenged after only five, instead of eighty, years; presumably, the President's action would not

plied authorization of Congress nor contrary to any express or implied declaration of Congress but instead seems to be acting in 'a zone of twilight in which he and Congress may have concurrent authority" " (quoting Youngstown, 343 U.S. at 637 (Jackson, J., concurring)).

43. 343 U.S. at 610 (Frankfurter, J., concurring).

44. This implies that an unapproved executive action could be struck down if attempts to invalidate it were made soon after its implementation, but that it could "mature" into authoritative law if no challenge were made and if Congress did not act. See Note, supra note 39, at 701; cf. United States v. Midwest Oil Co., 236 U.S. 459, 474 (1915) ("the long continued practice, known to and acquiesced in by Congress, would raise a presumption that the withdrawals [of land] had been made in pursuance of its consent or of a recognized administrative power of the Executive in the management of the public lands"). But see Kauper, The Steel Seizure Case: The President and the Supreme Court, 51 Mrch. L. REv. 141, 181 (1952) ("The burden should not be placed on Congress to take positive steps to negate an overreaching in the assertion of executive authority").

45. 236 U.S. 459 (1915).

46. For a very useful analysis of the distinctions between the character of executive authority exerted in Midwest Oil and Youngstown, see Kauper, supra note 44, at 165. See also Note, supra note 36 , at $60-61$.

47. 236 U.S. at 469 (President acted "without express statutory authority-but under claim of power so to do").

48. Id. at 482-83. See also Saxbe v. Bustos, 419 U.S. 65, 74 (1974) ("Such a history of administrative construction [of the Immigration and Nationality Act] and congressional acquiescence may add a gloss or qualification to what is on its face unqualified statutory language"); Zemel v. Rusk, 381 U.S. 1, 11 (1965) ("Congress' failure to repeal or revise in the face of such administrative interpretation has been held to constitute persuasive evidence that that interpretation is the one intended by Congress").

49. 343 U.S. at 610-11. 
have been upheld..$^{50}$ For this type of implied executive power to arise, there must be a period during which the acquiescence has an opportunity to develop. ${ }^{51}$ The determinative question in each case is whether the period of time over which the President has acted has been sufficiently long for the court to conclude that congressional acquiescence may be implied.

Even when the President acts in reliance upon a statute, his authority may be called into question when his action is not reasonably related to the "authorizing" statute. ${ }^{52}$ In such instances, the executive action in issue was neither clearly contemplated nor directly sanctioned by Congress. For example, the ability of the President to relieve employment discrimination is not addressed by any statute. However, the President may determine that the procurement statutes give him the power to require employers to adopt affirmative action plans. The theory supporting this exercise of power is that subsequent congressional inaction on the questioned executive authority-in this case, the power to require affirmative action schemes-may represent legislative acquiescence in the executive view, notwithstanding that the President initially lacked an unambiguous statutory foundation. Through its silence, Congress further explains how it intended the statute to operate, particularly in regard to the executive function. ${ }^{53}$ As in the case where the executive had no statute from which his authority was derived, a lack of congressional acquiescence would undermine such executive power. ${ }^{54}$

Determining whether the executive order draws its authority from constitutional or statutory underpinnings is not the purpose of this Note. Rather, it is sufficient to recognize that the source of the executive power, unless constitutionally based and completely independent of the powers of Congress, may be undercut by a lack of tacit congres-

50. See note 44 supra.

51. Similarly, in Youngstown the President relied upon statutory silence. In that case, however, there was no demonstration of congressional acquiescence. On the contrary, only a short time before the presidential order was issued Congress had rejected approval of the very means that Truman used to seize the steel mills. 343 U.S. at 602 .

52. It is not clear that the President's procurement authority supports his imposition of nondiscrimination policies upon government contractors. As one commentator notes, "[a]n objection to the exercise of power may be that nondiscrimination in employment by contractors is not clearly relevant to the Government's concern in contracting with them." Speck 250. Speck nevertheless cites numerous examples of executive orders issued by several Presidents prescribing the use of procurement contract clauses to achieve other objectives, absent statutory authorization. Id. 248 .

53. See Saxbe v. Bustos, 419 U.S. 65 (1974); Zemel v. Rusk, 381 U.S. 1 (1965); United States v. Midwest Oil, 236 U.S. 459 (1915).

54. See Youngstown, 343 U.S. at 610 (Frankfurter, J., concurring). See also Corwin, The Steel Seizure Case: A Judicial Brick Without a Straw, 53 ColuM. L. REv. 53, 61 (1952). 
sional approval or by contrary congressional expressions. For example, congressional action disapproving President Truman's means of settling a national labor dispute spelled defeat for his exercise of authority in Youngstown. Disregarding the specific source from which Executive Order No, 11,246 originated, if one is to rely upon the "independent powers" of the executive the crucial question becomes whether congressional disapproval has been manifested in a manner sufficient to defeat the affirmative action requirements of the order.

Considering the limited language of the procurement statutes, it is not readily apparent that the nondiscrimination clauses of Executive Order No. 11,246 were enacted pursuant to the "express or implied authorization of Congress." Consequently, one must look to the "independent power" source of the executive. One commentator argues that the "lack of any serious challenge" to the exercise of procurement authority "by four Presidents in nine executive orders over twenty years" lends support to presidential power to prescribe nondiscrimination. ${ }^{55}$ Certainly this position coincides with Justice Frankfurter's analysis in Youngstown that "a systematic, unbroken, executive practice, long pursued to the knowledge of the Congress and never before questioned" gives rise to the valid exercise of executive authority. ${ }^{56}$ Moreover, before the Civil Rights Act of 1964 was finally enacted, many pieces of legislation aimed at eliminating employment discrimination were presented to the Congress, but were never approved; ${ }^{57}$ such congressional inaction could evidence approval of the executive order program as well as disapproval of a more comprehensive scheme. ${ }^{58}$

55. Speck 246. The author goes on to point out that "prescription of contract clauses by executive order is older and almost as common as prescription by statute," id. 249, and that "even without statutory authorization several Presidents by executive order have prescribed use of procurement contract clauses to achieve other objectives." Id. 248.

56. 343 U.S. at 610 . See text accompanying note 43 supra.

57. See Miller, Government Contracts and Social Control: A Preliminary Inquiry, 41 VA. L. REv. 27 (1955). Professor Miller notes that several antidiscrimination bills were introduced in the 83d Congress. Senator Ives of New York, for example, authored S. 1831, making discrimination on the basis of race, religion, color or natural origin an unfair labor practice. Although this bill and other similar ones purporting to relieve discrimination were not passed, executive orders existing at the time required employment practices that Congress refused to authorize through legislation. It does not follow, however, that the failure to pass any of these bills evidenced legislative dissatisfaction with the executive order programs. A cogent argument could be made that by not rejecting the provisions of the order, Congress approved efforts to restrict government contractors, while disfavoring broader relief measures.

58. Nevertheless, just as the failure of a bill to become law does not necessarily evidence legislative dissatisfaction with similar, pre-existing programs of more limited scope than that proposed, neither can such congressional defeat be used to demonstrate legislative approval or acquiescence. See note 96 infra. The premise advanced here, as discussed by Professor Miller, see note 57 supra, is that since during the late 1950 s and early 1960 s Congress did consider implementing a comprehensive antidiscrimination employment scheme (similar to that eventually approved in the 
Finally, congressional acquiescence in the face of far-reaching affirmative action plans implemented on the authority of Executive Order No. 11,246 implies that Congress has granted the President, in the words of Justice Jackson, an "independent presidential responsibility" 59 to help relieve discriminatory employment practices. The degree of this prerogative, and whether it may be extended to the field of seniority rights, can be determined only by an analysis of recent congressional expressions concerning employment discrimination.

\section{The Civil Rights Act of 1964}

The most significant manifestation of congressional intent as to the policies that should govern the elimination of employment discrimination lies in the debates and reports dealing with the Civil Rights Act of $1964^{60}$ and subsequently enacted related legislation. ${ }^{61}$ Unfortunately, there existed only one reference in Title VII as originally enacted to the executive order program, ${ }^{62}$ and that was inserted without the benefit of debate or commentary. Moreover, Congress' intent in passing Title VII is unclear, ${ }^{63}$ although later legislative expressions help to clarify Congress' position.

\section{A. The Civil Rights Debates of 1964.}

Remarks and memoranda offered by legislators before section 703(h) was introduced suggest that Congress did not envision a seniority provision that might endanger established seniority rights. ${ }^{64}$ Sena-

Civil Rights Act of 1964) and was aware of the executive order program, it assented to the policy of holding government contractors to stricter antidiscrimination terms than other employers by not stripping the executive of the power to dictate and enforce such terms.

59. Youngstown, 343 U.S. at 637 (Jackson, J., concurring). The Philadelphia Plan, for instance, was implemented pursuant to Executive Order No. 11,246. It required that employers submit a statement of "goals" of minority employment together with their bids. These goals were to fall within a range established by the government. It seems clear, however, that $\& 703(j)$ of the Civil Rights Act alone would not authorize such a scheme. The lack of legislative action emphasizes Congress' apparent respect for measures such as the Philadelphia Plan that were implemented on the basis of "independent presidential responsibility." See Chicago Comment 747-50. For a general explanation of the Philadelphia Plan, see Comment, The Philadelphia Plan: Equal Employment Opportunity in the Construction Trades, 6 CoLUM. J.L. \& Soc. Prob. 187 (1970).

60. 42 U.S.C. $\$ \S 2000 \mathrm{a}$ to $2000 \mathrm{~h}-6$ (1976).

61. Equal Employment Opportunity Act of 1972, Pub. L. No. 92-261, 86 Stat. 103 (codified at 42 U.S.C. $\$ \S 2000$ e, $2000 \mathrm{e}-1$ to $2000 \mathrm{e}-6,2000 \mathrm{e}-8,2000 \mathrm{e}-9,2000 \mathrm{e}-13$ to $2000 \mathrm{e}-14,2000 \mathrm{e}-16$ to 2000e-17 (1976)).

62. Civil Rights Act of 1964, Pub. L. No. 88-352, § 709, 78 Stat. 241 (current version at 42 U.S.C. $\S 2000 \mathrm{e}-8(\mathrm{~d})$ (1976)), reprinted in part at note 94 infra. This provision relieved employers who filed reports under Executive Order No. 11,246 from the requirement of filing additional reports pursuant to Title VII. See text accompanying notes 94-97 infra.

63. See text accompanying notes 64-68 infra. See Note, supra note 1, at 1271.

64. See, e.g., 110 CONG. REC. 6563-64 (1964) (remarks of Sen. Kuchel) ("Neither would se- 
tor Clark, a floor manager of the bill and heralded as the "Senate Czar" of the Act, stated that the bill "would not affect seniority at all."65 The Interpretative Memorandum of Title VII written by Senators Clark and Case further elaborated:

Title VII would have no effect on established seniority rights. Its effect is prospective and not retrospective. Thus, for example, if a business has been discriminating in the past and as a result has an allwhite working force, when the title comes into effect the employer's obligation would be simply to fill future vacancies on a nondiscriminatory basis. ${ }^{66}$

The importance of this material has been widely questioned, however, since the relevant debates and documents predate by many weeks the Mansfield-Dirksen amendment containing section $703 .{ }^{67}$ As a result, the term "bona fide seniority system" was never clarified. Similarly, none of the legislative history of Title VII explicitly addresses the problems of seniority systems that perpetuate discrimination. ${ }^{68}$

\section{B. Judicial Interpretation of the Act.}

The courts have been forced to fit a nebulous and perhaps contradictory legislative directive into a complex matrix of employment variables. First, they had to define the meaning of "bona fide seniority

niority rights be affected by this act"). See generally Vaas, Title VII: Legislative History, 7 B.C. INDUS. \& COM. L. Rev. 431, $448-49$ (1966).

65. 110 CONG. REC. 7207 (1964).

66. Id. 7213.

67. See Watkins v. United Steel Workers Local 2369, 369 F. Supp. 1221, 1228 (E.D. La. 1974), rev'd on other grounds, 516 F.2d 41 (5th Cir. 1975). Judge Cassibry observed in Watkins:

Some weeks after Senator Clark inserted his memoranda in the Record, a bipartisan group of Senate leadership prepared another version of a Civil Rights Bill, including a new fair employment title ... . which was subsequently enacted. . . In view of this chronology, it seems proper to rely more heavily on the language of Section 703(h), and less on the earlier legislative statements than might otherwise be appropriate in interpreting the Act on questions of seniority.

369 F. Supp. at 1228 . Although the Watkins decision was later reversed by the Fifth Circuit, 516 F.2d 41 (5th Cir. 1975), the circuit court apparently accepted the district court's interpretation of the legislative history of $\S 703(\mathrm{~h})$, basing its reversal upon a factual error: "The district court had no basis in fact for the decision that the Company's history of racial discrimination in hiring makes it impossible for blacks to have sufficient seniority to withstand layoff . . ." Id. at 46 . For a helpful consideration of the Fifth Circuit's modification of Judge Cassibry's opinion, see Edwards \& Zaretsky, Preferential Remedies for Employment Discrimination, 74 Mich. L. REv. 1, 43-45 (1975).

68. One commentator has observed that

Congress did not, at any point in the debate or related hearings, directly confront the problem of seniority systems in which discrimination had subordinated Negro workers to whites of equal or lessor tenure. As the Clark-Case memorandum indicates, proponents of Title VII concentrated on refuting charges that the bill authorized "reverse discrimination" and that it would interfere with the rormal operation of nondiscriminatory seniority systems.

Note, supra note 1, at 1271. 
system," determining whether an agreement that was facially neutral was "bona fide." Second, the courts had to examine the character of relief that was warranted by the Act. Basically, there were three possibilities: $^{69}$ first, retroactively erasing all vestiges of past discrimination by elevating minorities and, accordingly, demoting other individuals as if the discrimination had never existed; second, granting prospective relief by allowing minority members to have elevated seniority status corresponding to the amount of time they had spent in "minority jobs"; ${ }^{\prime 0}$ or, third, limiting the elevated seniority status of minorities to the amount of time they had spent in "minority" jobs after the passage of the Act. Another salient question was whether Congress had intended a different result when the provisions involved "departmental," as opposed to "plant-wide," seniority. ${ }^{71}$ Finally, the courts were faced with seemingly contradictory language within the Act itself. Section 716(a) declared a broad remedial policy, making unlawful any classification of employees that would "tend to deprive any individual of employment opportunities or otherwise adversely affect his status as an employee, because of such individual's race, color, religion, sex, or national origin." 72 The question remained whether the seniority area was meant to be exempt from this sweeping mandate.

Before Teamsters, the virtually unanimous view of the courts was that section 703(h) did not immunize seniority systems that perpetuated the effects of prior discrimination, even discrimination resulting from facially neutral programs. ${ }^{73}$ Referring to this judicial solidarity, Justice Marshall, concurring in part and dissenting in part in Teamsters, observed:

Without a single dissent, six Courts of Appeals have so held in over 30 cases, and two other Courts of Appeals have indicated their agreement, also without dissent. In an unbroken line of cases, the Equal Employment Opportunity Commission has reached the same conclu-

69. For a more detailed analysis of these approaches, see Note, supra note 1, at 1268-75. The writer refers to these categories respectively as (1) "freedom now," (2) "rightful place" and (3) "status quo."

70. This solution would not displace nonminority workers, but would give the minority employee an advantage when new jobs became available. The term "minority" jobs refers to those jobs traditionally held by minority employees.

71. See Quarles v. Philip Morris, Inc., 279 F. Supp. 505, 516 (E.D. Va. 1968) (court noted that the legislative history contains no express statement about departmental seniority).

72. 42 U.S.C. $\$ 2000 \mathrm{e}-2(\mathrm{a})(2)(1976)$.

73. See, e.g., Gibson v. Longshoremen, 543 F.2d 1259 (9th Cir. 1976); Nance v. Union Carbide Corp., 540 F.2d 718 (4th Cir. 1976), cert denied, 431 U.S. 953 (1977); Swint v. PullmanStandard, 539 F.2d 77 (5th Cir. 1976); Acha v. Beame, 531 F.2d 648 (2d Cir. 1976); EEOC v. Detroit Edison Co., 515 F.2d 301 (6th Cir. 1975), remanded for reconsideration in light of Teamsters, 431 U.S. 951 (1977); United States v. N.L. Industries, Inc., 479 F.2d 354 (8th Cir. 1973). See authorities cited at Teamsters, 431 U.S. at 346 n.28. 
sion. And the overwhelming weight of scholarly opinion is in accord. ${ }^{74}$

These decisions were premised on a variety of rationales. Some courts simply questioned the applicability of the legislative history, stating that the chronology of the Act's passage did not demonstrate that the "bona fide" language was closely enough related to the earlier debates $^{75}$ or that the legislators' statements did not concern the particular seniority system in question, ${ }^{76}$ such as departmental seniority. One such court opined that a necessary "characteristic of a bona fide seniority system must be lack of discrimination."77 Other decisions suggested that legislative history could be ignored in order to achieve the overriding intent of the Act. ${ }^{78}$ The test under this standard was "whether the practices in question [had] any present discriminatory effect."79 From such an analysis emerged the famous interpretation in Quarles v. Philip Morris, Inc. ${ }^{80}$ that "Congress did not intend to freeze an entire generation of Negro employees into discriminatory patterns that existed before the Act."81 This position was later adopted by the Supreme Court in Griggs v. Duke Power Co. ${ }^{82}$ Still other courts accepted the section 703(h) comments as useful congressional expressions, but contended that these statements did not legalize seniority systems that perpetuated discrimination. ${ }^{83}$ These courts apparently reasoned that

74. 431 U.S. at $378-80$ (footnotes omitted). See authorities cited $i d$. at 378 n.2, 379 n.3 \& 380 nn.4-5.

75. See, e.g., Watkins v. United Steel Workers Local 2369, 369 F. Supp. 1221 (E.D. La. 1974), rev'd on other grounds, 516 F.2d 41 (5th Cir. 1975).

76. See, e.g., Quarles v. Philip Morris, Inc., 279 F. Supp. 505 (E.D. Va. 1968). But cf. Jersey Cent. Power \& Light Co. v. Local 327, IBEW, 508 F.2d 687, 705 (3d Cir. 1975), cert. denied, 425 U.S. 998 (1976) ("Our reading of Title VII reveals no statutory proscription of plant-wide seniority systems"). nal).

77. Quarles v. Philip Morris, Inc., 279 F. Supp. 505, 517 (E.D. Va. 1968) (emphasis in origi-

78. See Watkins v. United Steel Workers Local 2369, 369 F. Supp. 1221, 1228 (E.D. La. 1974), rev'd on other grounds, 516 F.2d 41 (5th Cir. 1975); $c f$. United States v. Jacksonville Terminal Co., 451 F.2d 418, 451 (5th Cir. 1971) (a district court "is not limited to simply parroting the Act's prohibitions but is required to order such affirmative action as may be appropriate."). See also United States v. Local 638, Enterprise Ass'n of Pipefitters, 347 F. Supp. 169, 181 (S.D.N.Y. 1972).

79. United States v. Local 638, Enterprise Ass'n of Pipefitters, 347 F. Supp. 169, 181 (S.D.N.Y. 1972) (emphasis in original).

80. 279 F. Supp. 505 (E.D. Va. 1968).

81. Id. at 516 .

82. 401 U.S. 424 (1971).

83. E.g., Nance v. Union Carbide Corp., 540 F.2d 718 (4th Cir. 1976); Acha v. Beame, 531 F.2d 648 (2d Cir. 1976); see International Brotherhood of Teamsters v. United States, 431 U.S. 324, 384 (Marshall, J., concurring in part and dissenting in part) ("Had the Court objectively examined the legislative history, it would have been compelled to reach the opposite conclusion") (citing Franks v. Bowman Transp. Co., 424 U.S. 747 (1976)). 
Congress did not intend to upset seniority expectations that had developed prior to the enactment of Title VII, but did mean to disturb such expectations arising thereafter "to the extent that those expectations were dependent upon whites benefiting from unlawful discrimination." 84 Finally, subsequent legislative actions manifested approval of early court decisions liberally construing section $703(\mathrm{~h}),{ }^{85}$ affording an even more substantial foundation for later decisions. ${ }^{86}$

In Teamsters, the Supreme Court reviewed its repeated holdings that a prima facie Title VII violation could be established by practices that are neutral in intent but nonetheless are de facto discriminatory. Although the facially neutral practice in Teamsters, as in East Texas Motor Freight, perpetuated the effects of prior discrimination, Justice Stewart in the Court's majority opinion rejected the applicability of Griggs with regard to "bona fide" seniority systems. ${ }^{87}$ Basing its decision upon the notion that the pre-section 703(h) congressional statements were authoritative as to the purpose of Title VII, the Court stated that section 703(h) did not condemn de facto discrimination left frozen under existing seniority policies. ${ }^{88}$ The only remedy available, according to the Court, was the awarding of retroactive seniority to employees who sought relief from intentional post-Act discrimination, expanding a policy earlier articulated in Franks v. Bowman Transportation $\mathrm{Co}^{89}$ regarding hiring discrimination. ${ }^{90}$ Although the restrictive-

84. Teamsters, 424 U.S. at 484 (Marshall, J., concurring in part and dissenting in part).

85. See Equal Employment Opportunity Act of 1972, Pub. L. No. 92-261, 86 Stat. 103 (codified at 42 U.S.C. $\$ \$ 2000 \mathrm{e}, 2000 \mathrm{e}-1$ to $2000 \mathrm{e}-6,2000 \mathrm{e}-8,2000 \mathrm{e}-9,2000 \mathrm{e}-13$ to $2000 \mathrm{e}-14,2000 \mathrm{e}-16$ to $2000 \mathrm{e}-17$ (1976).

86. E.g., United States v. New Orleans Pub. Serv., Inc., 553 F.2d 459, 467 (5th Cir. 1977), vacated and remanded on other grounds, 98 S. Ct. 2841 (1978); Crown Zellerbach Corp. v. Marshall, 441 F. Supp. 1110 (E.D. La. 1977). See generally 118 CoNG. REC. 3371 (1972) (remarks of Sen. Williams) ("the courts have repeatedly proposed a multifaceted approach to employment discrimination, to bring to bear the full force of the law on this problem. . . The law against employment discrimination did not begin with title VII and the EEOC, nor is it intended to end with it"). Congress apparently agreed with the broad approach encouraged by the courts, for it rejected attempts to make Title VII the exclusive remedy. See text accompanying notes 99-101 infra. See generally Chicago Comment 747-57.

87. 431 U.S. at 349. The Teamsters court stated that "[w]ere it not for $\S 703(\mathrm{~h})$, the seniority system in this case would seem to fall under the Griggs rationale." Id. Griggs involved the requirement of a high school diploma or passage of an intelligence test as a condition to employment in or transfer to jobs at a manufacturing plant. The decision did not, however, reach the issue of discrimination arising from seniority practice.

88. Justice Stewart observed:

This disproportionate distribution of advantages does in a very real sense "operate to 'freeze' the status quo of prior discriminatory practices." But both the literal terms of $\$$ 703(h) and the legislative history of Title VII demonstrate that Congress considered this very effect of many seniority systems and extended a measure of immunity to them.

431 U.S. at 350.

89. 424 U.S. 747 (1976). 
ness that marks the Teamsters interpretation may be criticized, the section 703(h) issue is now a settled question of law. Since the Court dealt only with Title VII, however, and not with additional remedies, it is unclear whether other laws may provide relief that cannot be achieved under the Act. ${ }^{91}$

\section{Title VII-A Nonexclusive Remedy.}

The courts have increasingly noted that "the remedies established by Title VII are not exclusive." 92 Moreover, there is ample authority that section $703(\mathrm{~h})$ is a limitation only upon Title VII and not upon other laws, including executive orders, that seek to relieve discrimination in seniority agreements. ${ }^{93}$ At least two cogent arguments exist for this narrow construction of the Act. First, a reference to executive orders in section 709(d) of the Civil Rights Act as originally enacted implies that Congress intended that the executive order program would continue in existence. ${ }^{94}$ The language of section 709(d) demonstrates that Congress recognized the "requirements" of the order. Although all reference to "executive orders" was deleted from this section by the 1972 amendments to the Civil Rights Act, ${ }^{95}$ this later action repre-

90. 431 U.S. at 356 . Justice Stewart correctly envisioned the crippling effect that this interpretation would render upon seniority rights:

Where, because of the employer's prior intentional discrimination, the line drivers with the longest tenure are without exception white, the advantages of the seniority system flow disproportionately to them and away from Negro and Spanish surnamed employees who might by now have enjoyed those advantages had not the employer discriminated before the passage of the Act. Id. at 349-50.

91. The obvious question is whether Title VII affects the relief outlined by Executive Order No. 11,246. There are other statutory overlaps of Title VII, however. For instance, concern over the relationship between Title VII and the remedies provided under the National Labor Relations Act has been frequently expressed. See Comment, The Inevitable Interplay of Title VII and the National Labor Relations Act: A New Role for the NLRB, 123 U. PA. L. REv. 158 (1974).

92. Contractors Ass'n of E. Pa. v. Secretary of Labor, 442 F.2d 159, 171 (3d Cir.), cert. denied, 404 U.S. 854 (1971); see EEOC v. American Tel. \& Tel, Co., 556 F.2d 167, 175 (3d Cir. 1977); United States v. New Orleans Pub. Serv., Inc., 553 F.2d 459, 467 (5th Cir. 1977), vacated and remanded on other grounds, $98 \mathrm{~S}$. Ct. 2841 (1978).

93. See, e.g., Contractors Ass'n of E. Pa. v. Secretary of Labor, 442 F.2d 159, 172 (3d Cir.), cert. denied, 404 U.S. 854 (1971); Crown Zellerbach Corp. v. Marshall, 441 F. Supp. 1110, 1121 (E.D. La. 1977). See generally St. Antoine, supra note 24, at 37-42.

94. Section 709(d) (current version at 42 U.S.C. $\$ 2000 \mathrm{e}-8$ (d) (1976) provided in pertinent part:

Where an employer is required by Executive Order 10925, issued March 6, 1961, or by any other Executive order prescribing fair employment practices for Government contractors and subcontractors, . . . to file reports relating to his employment practices with any Federal agency or committee, ... the Commission shall not require him to file additional reports pursuant to ... this section.

95. Equal Employment Opportunity Act of 1972, Pub. L. No. 92-261, § 6, 86 Stat. 103 (codified at 42 U.S.C. $\$ 2000 \mathrm{e}-8(\mathrm{~d})(1976)$ ). 
sented an effort to streamline the record keeping and reporting requirements of the Act, rather than a refusal to recognize the requirements of the executive order programs. ${ }^{96}$ In demanding reports on the achievement of those requirements by employers, Congress apparently assented to the executive policy. ${ }^{97}$ Just as Congress had acquiesced in the promulgation of earlier executive orders whose scope exceeded that of contemporary antidiscrimination statutes by its failure to invalidate the orders, the legislature similarly appears to have accepted in the Civil Rights Act of 1964 a stricter standard for federal contractors than for other employers. Congress not only neglected to strike down Executive Order No. 11,246, but also legitimated it by statutory reference, thus evidencing an intent to render the Act a nonexclusive remedy.

Second, the legislative history of the 1972 amendments to Title VII, popularly known as the Equal Employment Opportunity Act of 1972,98 erased doubts as to the legality of the executive order's liberal remedial measures. A series of attempts to amend the Equal Employment Opportunity Act sought to confine the authority of Executive Order No. 11,246 within the bounds of Title VII. ${ }^{99}$ Legislative sentiment in support of the executive order program surfaced in successful opposition to a renewed attempt to make Title VII the exclusive federal remedy. Three amendments offered by Senator Ervin were defeated: ${ }^{100}$ first, to merge the Equal Employment Opportunity Commission (EEOC) and the Office of Federal Contract Compliance (OFCC), creating an agency that derived its power solely from Title VII; second, generally to prohibit "discrimination in reverse"; and, finally, to make the OFCC abide by section 703(a), which rendered preferential treat-

96. See commentary to subsec. (d) following 42 U.S.C. $\$ 2000$ e-8 (1976); H.R. REP. No. 238, 92d Cong., 1st Sess. 29, reprinted in [1972] U.S. Code Cong. \& AD. NEws 2137, 2164.

Some commentators contend, however, that although affirmative action provisions were contained in the Act during that time, they had never actually been utilized. Hence, according to these writers, the idea that Congress implicitly approved such preferential relief is spurious. Following this line of reasoning, the Comptroller General concluded that the Philadelphia Plan was in conflict with the Civil Rights Act of 1964:

[W]hile the phrase "affirmative action" was included in the Executive order (10925), which was in effect at the time Congress was debating the bills which were subsequently enacted as the Civil Rights Act of 1964, no specific affirmative action requirements of the kind here involved had been imposed upon contractors under authority of that Executive order at that time, and we therefore do not think it can be successfully contended that Congress, in recognizing the existence of the Executive order and in failing to specially legislate against it, was approving or ratifying the type or methods of affirmative action which [the Department of Labor] now proposes to impose upon contractors.

49 Comp. Gen. 59, 70-71 (1969), quoted in Chicago Comment 735 n.68.

97. See note 57 supra.

98. Pub. L. No. 92-261, 86 Stat. 103 (codified at 42 U.S.C. $\$ \S 2000 \mathrm{e}, 2000 \mathrm{e}-1$ to $2000 \mathrm{e}-6$, $2000 \mathrm{e}-8,2000 \mathrm{e}-9,2000 \mathrm{e}-13$ to $2000 \mathrm{e}-14,2000 \mathrm{e}-16$ to $2000 \mathrm{e}-17$ (1976)).

99. See Chicago Comment 753-57.

100. See id. 754-57. 
ment illegal. ${ }^{101} \mathrm{Had}$ these amendments been approved by Congress, the nondiscrimination clause in Executive Order No. 11,246 could no longer have directed remedies more stringent than those available under Title VII. Moreover, unequivocal approval of the executive program-which by this time very obviously employed affirmative action-emerged in the debates. ${ }^{102}$

The above discussion indicates that the alternative remedy provided by the executive order manifests presidential authority "at its maximum," for the order was issued pursuant to "an express or implied authorization of Congress." 103 However, specific remedies granted pursuant to the order, or interpretations of the order urged upon the courts, may fly in the face of congressional intentions. ${ }^{104}$ Given that Congress has endorsed the executive order program but that the authority of the executive is not unbounded, the standards imposed by Youngstown must be applied to determine the effect of executive-created employment rights.

\section{The Application of Executive ORder No. 11,246 to SENIORITY RIGHTS}

As previously demonstrated, ${ }^{105}$ the President can obtain the power

101. Section 703(a) (codified at 42 U.S.C. $\$ 2000 \mathrm{e}-2$ (a) (1976)) provides in part:

It shall be an unlawful employment practice for an employer . . . (2) to limit, segregate, or classify his employees or applicants for employment in any way which would deprive or tend to deprive any individual of employment opportunities or otherwise adversely affect his status as an employee, because of such individual's race, color, religion, sex, or national origin.

102. See 118 CONG. ReC. $3371-72$ (1972) (remarks of Sen. Williams) ("this amendment can be read to bar enforcement of the Government contract compliance program . . . . I cannot believe that the Senate would do that after all the votes we have taken in the past 2 or 3 years to continue that program in full force and effect." Id. 3372); id. 3962, 3964 (remarks of Sen. Javits); Weber v. Kaiser Aluminum \& Chem. Corp., 563 F.2d 216, 237 (5th Cir. 1977), cert. granted, 99 S.Ct. 720 (1979) (Wisdom, J., dissenting) ("Congress has implicitly exempted the Executive Order from the constraints of Title VII") (footnote omitted); United States v. New Orleans Pub. Serv., Inc., 553 F.2d 459, 467 (5th Cir. 1977), vacated and remanded on other grounds, 98 S. Ct. 2841 (1978) ("the debates surrounding the Equal Opportunity Act of 1972 offer additional evidence of congressional approval [of Exec. Order No. 11,246]"); Edwards \& Zaretsky, supra note 67, at 30 ("The Executive Order received implied legislative approval during the consideration of the 1972 amendments to the Civil Rights Act of 1964"); Note, Imposition of Affirmative Action Obligations on Nonconsenting Government Contractors, 91 HARv. L. REv. 506, 514 (1977) ("in 1972, [Congress] ratified the Executive Order program").

103. 343 U.S. at 635 (Jackson, J., concurring). See text accompanying note 35 supra. Affirmative action schemes such as the Philadelphia Plan, see note 59 supra, initially achieved their force through congressional "inertia, indifference, or quiescence" that invited "measures on individual presidential responsibility." 343 U.S. at 637 (Jackson, J., concurring). Eventually, when Congress examined its position on affirmative action requirements, the presidential authority to implement such plans moved from Justice Jackson's second category into his first.

104. See text accompanying notes $124-25$ infra.

105. See text accompanying notes 34-54 supra. 
to issue an executive order from the expression or implication of a statute or the Constitution, from legislative expressions or implications, or from congressional acquiescence. ${ }^{106}$ In light of these limitations and the congressional expressions concerning employment discrimination, ${ }^{107}$ the crucial question concerns the extent of the President's authority to grant retroactive relief from discrimination in seniority agreements through Executive Order No. 11,246. The President's procurement authority to establish "an economical and efficient system for the procurement and supply of property and services" 108 arguably gives him the power "to assure utilization of all segments of society in the available labor pool for government contractors . . . ."109 Under this theory, by elevating the seniority of affected minority employees to levels that they would have achieved absent the discrimination, the President would be assuring a proper distribution of minorities in the work force. ${ }^{110}$

Interference with a bona fide seniority system through the executive order was approved in Contractors Association of Eastern Pennyslvania $v$. Secretary of Labor, ${ }^{111}$ where the court observed that federal construction contracts involved an area "in which discrimination in employment was most likely to affect the cost and the progress of projects in which the federal government had both financial and completion interests." 112 Certainly, there is economic justification in favor of enforcing affirmative action terms in government contracts. ${ }^{113}$

106. Although much authority of the executive lacks explicit statutory approval, there is typically implicit legislative acceptance of the President's action or a delegation of authority to the President by the Constitution. Without any of these sources of executive authority, the order lacks the foundation necessary to become law. But if the order, or any portion of it, is sufficiently supported by one or more of these sources, it should be sustained.

107. See text accompanying notes 60-104 supra.

108. 40 U.S.C. $\$ 486$ (a) (1976).

109. EEOC v. American Tel. \& Tel. Co., 556 F.2d 167, 175 (3d Cir. 1977). See note 24 supra. Professor St. Antoine observes that minorities are severely underrepresented in the current labor pool. They are "twice as likely as whites not to have jobs" and they "occupy a disproportionately low percentage of the more attractive positions." St. Antoine, supra note 24, at 28-29.

110. One convincing argument against allowing the President to provide retroactive seniority relief to minority workers is that such a directive would represent the imposition of his particular notions of desirable social legislation and would refiect a policy that is neither economically necessary nor advisable. See Miller, supra note 57, at 37-43. But see Contractors Ass'n of E. Pa. v. Secretary of Labor, 442 F.2d 159, 171 (3d Cir.), cert. denied, 404 U.S. 854 (1971).

111. 442 F.2d 159 (3d Cir.), cert. denied, 404 U.S. 854 (1971).

112. 442 F.2d at 171 .

113. In 1955 a study determined that the annual cost of discrimination is approximately $\$ 30$ billion per year in unutilized skills and in markets lost through failure to spread purchasing power to minorities. See Pasley, supra note 24, at 867-68. Justice Marshall stated in Teamsters that "the backers of Title [VII] viewed economic equality as both a practical necessity and a moral imperative." 431 U.S. at 388 (Marshall, J., concurring in part and dissenting in part). 
But even if the executive order's broad remedial measures are viewed as an abuse of the procurement authority, the evidence that Congress has acquiesced to or approved the sort of seniority relief requested in East Texas Motor Freight provides an alternative source of executive authority. ${ }^{114}$

Although Congress never expressly approved retroactive seniority relief through the executive order, it has endorsed affirmative action schemes of the same magnitude. ${ }^{115}$ Moreover, it is not necessary that "congressional ratification of the particular aspect of the Executive Order program . . . at issue" 116 be demonstrated, especially if a congressional attitude can be discerned. ${ }^{117}$ Such an attitude does surface in the rejection of the proposed amendments to the Equal Employment Opportunity Act of $1972 .{ }^{118}$ Implicit congressional approval of the Philadelphia Plan ${ }^{119}$ - which required that employers submit a statement of "goals" of minority employment when submitting bids ${ }^{120}$ and which was interpreted as mandating interference with "bona fide" seniority systems ${ }^{121}$-invited "measures on independent presidential responsibility" 122 to eradicate the vestiges of past discrimination through affirmative action programs. In view of this implication and of the absence of any congressional prohibition, the President could lawfully make federal contractors accede to affirmative action plans granting minority workers retroactive seniority relief. ${ }^{123}$

114. See text accompanying notes $41-59$ supra.

115. See Chicago Comment 747-50. See notes 59 \& 103 supra.

116. United States v. New Orleans Pub. Serv., Inc., 553 F.2d 459, 467 (Sth Cir. 1977), vacated and remanded on other grounds, 98 S. Ct. 2841 (1978). The New Orleans court applied the order, notwithstanding that Congress had not ratified the aspect of the program at issue.

117. A court can effectively "interpolate" from congressional expression the general character of relief that the legislature would allow. By endorsing the Philadelphia Plan, see note 59 supra, for example, Congress suggested that it would assent to similar policies.

118. See text accompanying note 99-102 supra.

119. See Chicago Comment 747-50. See notes 59 \& 103 supra.

120. See note 59 supra.

121. See Contractors Ass'n of E. Pa. v. Secretary of Labor, 442 F.2d 159, 172 (3d Cir.), cert. denied, 404 U.S. 854 (1971) (plaintiff's contention).

122. Youngstown, 343 U.S. at 637 (Jackson, J., concurring). The tacit approval of Congress elicits other similar-and perhaps more controversial-actions by the President in the area of employment discrimination.

123. Such plans apparently would not involve any constitutionally prohibited brand of "reverse discrimination." Affirmative action schemes are not unconstitutional where such racial preferences serve "a compelling governmental interest and are the least drastic means of accomplishing an appropriate end." St. Antoine, supra note 24, at 35. See generally Note, $A$ Proposal for Reconciling Affirmative Action with Nondiscrimination Under the Contractor Antidiscrimination Program, 30 StAN. L. REv. 803 (1977). Where "preferential treatment is a necessary step toward a more fully integrated work force and toward genuine equality of employment opportunity, then no constitutional barriers should stand in the way." St. Antoine, supra note 24, at 35. 
While the remedy of granting retroactive seniority is appropriate, it is easy to posit an abuse of presidential discretion under the order. For example, if instead of directing prospective relief through retroactive seniority a President demanded the immediate demotion of whites and the advancement of minorities, three formidable attacks could be launched. First, it is not apparent that such a remedy is reasonably related to the procurement authority. ${ }^{124}$ Second, even if economic advantages could be claimed, such a remedy is not analogous to any schemes that Congress has expressly or implicitly authorized. ${ }^{125}$ Thus, no congressional support is manifested. Finally, whereas there had been signs of legislative acquiescence to the granting of retroactive seniority, such "inaction" would undoubtedly instantaneously be transferred into congressional outrage, thus invalidating the implied authority.

However, where the effect of the remedy is not so severe as to trig-

Apparently, the recent decision in Regents of the Univ. of Cal. v. Bakke, 98 S. Ct. 2733 (1978), does not proscribe the preferential treatment afforded minorities under Executive Order No. 11,246. Only Justice Powell reached the conclusion that the quota system employed by the university was constitutionally infirm because it denied nonminority applicants equal protection in the context of an educational system. Four other justices (who, with Powell, formed the majority that upheld the decision of the California Supreme Court) held that the university had violated Title VII of the Civil Rights Act, which was not applicable in East Texas Motor Freight. Interestingly, however, the four justices who did not agree that the special admissions program was unlawful noted the scope of Title VII and Executive Order No. 11,246, lending further support to the view that the order is not limited by the statute and that it may provide broad relief:

In 1965, the President issued Executive Order 11246, 30 Fed. Reg. 12319, as amended 32

Fed. Reg. 14303, which required federal contractors to take affirmative action to remedy

the disproportionately low employment of racial minorities in the construction industry.

The Attorney General issued an opinion concluding that the race consciousness required by Executive Order 11246 did not conflict with Title VII:

"It is not correct to say that Title VII prohibits employers from making race or national origin a factor for consideration at any stage in the process of obtaining employees. The legal definition of discrimination is an evolving one, but it is now well recognized in judicial opinions that the obligation of nondiscrimination, whether imposed by statute or by the Constitution, does not require and, in some circumstances, may not permit obliviousness or indifference to the racial consequences of alternative courses of action which involve the application of outwardly neutral criteria."

[42 Op. ATT'y Gen. No. 37, at 7 (1969).]

The federal courts agreed. . . . Moreover, Congress, in enacting the 1972 amendments to Title VII, explicitly considered and rejected proposals to alter Executive Order 11246 and the prevailing judicial interpretations of Title VII as permitting, and in some circumstances requiring, race conscious action.

$98 \mathrm{~S}$. Ct. at $2781 \mathrm{n} .28$ (Brennan, J., concurring in part and dissenting in part).

124. The argument for enforcing the seniority rights of minorities, if based upon the presidential procurement power, is that such a policy will provide utilization of all segments of society in the labor pool. The demotion of whites would be contrary to this aim.

125. It is very clear from congressional expressions in both 1964 and 1972 that demotion of whites to enforce minority rights is disfavored. See, e.g., Vaas, supra note 64, at 450 . It is important to recognize, however, that relieving discrimination in a "bona fide system" does not demand such drastic remedies as demotion of nonminorities. 
ger congressional disapproval, congressional acquiescence further strengthens the remedy. The courts have in fact been willing to give effect to the requirements of nondiscrimination mandated by the order in situations closely analogous to that presented by the claimants in East Texas Motor Freight. In Contractors Association of Eastern Pennsylvania, the Third Circuit upheld executive interference with bona fide seniority systems, noting "that $\S 703(\mathrm{~h})$ is a limitation only upon Title VII." ${ }^{126}$ A recent district court case ${ }^{127}$ squared this position with Teamsters: "Teamsters did not in any sense indicate that retroactive seniority would violate the Act . . . . Title VII is intended to govern only private contracts, and not contracts with the government." 128 Indeed, the notable absence of any mention of Contractors Association of Eastern Pennsylvania by the Teamsters Court suggests that the Teamsters decision imposed a limitation only upon Title VII. The Court sought to give effect to congressional sentiment that the Act should not violate seniority "expectations" which had developed prior to its enactment. ${ }^{129}$ By using the "expectation analysis," the Court recognized that government contractors should have anticipated the employment of affirmative action schemes since they expressly agreed to a clause that makes affirmative action possible. Hence, because government contractors possess no justification for expecting that pre-Act discrimination is immunized, the Court narrowed its consideration to that category of employers that did not contract with the government and justifiably expected the application only of Title VII. Therefore, the less burdensome requirements of Title VII applied to the defendants in Teamsters. Both judicial interpretations and congressional expressions supply ample rationale for allowing the executive order to direct retroactive seniority relief.

\section{The Decision In East Texas Motor Freight}

Given that under Executive Order No. 11,246 the President can lawfully direct retroactive seniority relief, the final question is whether the Fifth Circuit in East Texas Motor Freight properly rejected claims for such relief. The court rejected application of the executive order on several grounds: first, that no action can be taken under the executive order against a labor union unless the union is "engaged in work under government contracts," which the union in East Texas Motor Freight

126. 442 F.2d at 172.

127. Crown Zellerbach Corp. v. Marshall, 441 F. Supp. 1110 (E.D. La. 1977).

128. Id. at 1121 .

129. 431 U.S. at $352-54$. 
was not; ${ }^{130}$ second, that even if an action could be brought against the union, the only action authorized would be through Title VII, which under Teamsters could not apply; ${ }^{131}$ third, that although section 209(a)(2) of the order speaks of enjoining "organizations" that "prevent compliance with the provisions of the order," the only action available would be the enforcement of contract provisions, which would not include the awarding of retroactive seniority relief; ${ }^{132}$ and, finally, that even if authorization of a remedial action against the union were contained in the order, a bona fide seniority system is lawful. ${ }^{133}$ These conclusions demonstrate either the court's misreading of or its disregard for the executive order, congressional intent and recent case law.

The court incorrectly stated that actions against unions may only involve those unions "engaged in work under government contracts"134 and that such relief must proceed through Title VII. ${ }^{135}$ While such an alternative is provided by the order, section 209(a)(2) apparently also allows an action against unions involved in work under private contracts. ${ }^{136}$ An employer, such as East Texas Motor Freight, that is engaged in any amount of work under a government contract agrees to take affirmative action to assure that no discrimination will exist at any of its facilities" 137 in the areas of "upgrading, demotion, or transfer; . . . layoff or termination; rates of pay or other forms of compensation . . . ."138 In other words, all employment, whether involved in the fulfillment of either government or private contracts, is subject to the terms of the executive order. In East Texas Motor Freight the union had stepped into the shoes of the employer, since the company under a consent decree had left the seniority provisions in the union agreement for resolution between the United States and the union. ${ }^{139}$ Hence, the union could properly be brought under the language of section 209(a)(2) as an "organization" that seeks "to prevent directly or indi-

130. 564 F.2d at 184 .

131. Id.

132. Id. The court hinted that the only remedy available to the government would be to enforce contract provisions by way of damages or an injunction. Id.

133. Id. at 185 .

134. Id. at 184 (quoting $\S 209$ (a)(3), 3 C.F.R. 340 (1964-1965 Compilation)).

135. 564 F.2d at 184 .

136. See text accompanying notes $139-43$ infra.

137. Exec. Order No. 11,246, $\S 204,3$ C.F.R. 340 (1964-1965 Compilation), reprinted in 42 U.S.C. following $\S 2000 \mathrm{e}(1976)$.

138. Exec. Order No. 11,246, $\S 202(1), 3$ C.F.R. 340 (1964-1965 Compilation), reprinted in 42 U.S.C. following $\$ 2000 \mathrm{e}(1976)$.

139. 564 F.2d at 181 ("The consent decree settled all issues between the United States and [East Texas]. . . . It did not affect seniority provisions of union agreements but left these for resolution after trial of the issues between the United States and the Union"). 
rectly compliance" with the executive order, ${ }^{140}$ even though the union itself was not engaged in work under government contracts.

As the court noted in Joyce v. McCrane, ${ }^{141}$ in holding that the affirmative action requirements of the executive order apply with equal force to employers and unions,

[in] any matter that deals with the regulation of this work force the unions must be proper parties. To rule otherwise would defeat the intention of Executive Order No. 11246, in that the government could bind the contractors to affirmative action yet this would be meaningless as the contractors could contract away this obligation through collective bargaining agreements with the unions. ${ }^{142}$

Thus, the union in East Texas Motor Freight is covered by the order because the government can demand, pursuant to its contract with the employer, that affirmative action be undertaken to eliminate discrimination arising from facially neutral seniority provisions. ${ }^{143}$

The East Texas Motor Freight court also held that even if an action against the union were appropriate, "it would necessarily be an action to enforce contract provisions by way of damages or an injunction." 144 The court added that "nothing in the Order suggests any authority to direct retroactive seniority benefit $[\mathrm{s}] . " 145$ Such a restrictive interpretation is supported neither by case law nor by the language of the order. The explicit section 209(a)(2) remedy of enforcing contract provisions encompasses broad equitable relief through its use of the phrase "appropriate proceedings." 146 In United States v. Duquesne Light $\mathrm{Co} .{ }^{147}$ the court observed that "[b]y its reference to 'appropriate proceedings,' $\& 209$ (a)(2) confers on the government discretion to invoke the equitable powers of [the] Court."148 Although nowhere in the

140. Exec. Order No. 11,246, \& 209(a)(2), 3 C.F.R. 340 (1964-1965 Compilation), reprinted in 42 U.S.C. following $§ 2000$ e (1976).

141. 320 F. Supp. 1284 (D.N.J. 1970).

142. Id. at 1291 .

143. Clearly, the practice involved in East Texas Motor Freight presents a type of discrimination subject to the prohibitions of the order. Minorities were confined to the most undesirable jobs for many years. If those employees subsequently transferred to better jobs, they forewent the seniority status they acquired in their previous positions. By maintaining their more secure status of seniority, the employees did not risk layoffs or loss of benefits as they would if they shifted to the OTR jobs, yet they received less pay and were precluded from advancement. The discriminatory effects of originally limiting minority workers to city lines were perpetuated through a facially neutral seniority system. An entire generation of Negroes was frozen into "the status quo of prior discriminatory employment practices." Griggs v. Duke Power Co., 401 U.S. 424, 430 (1971).

144. 564 F.2d at 184.

145. Id.

146. Exec. Order No. 11,246, § 209(a)(2), 3 C.F.R. 340 (1964-1965 Compilation), reprinted in 42 U.S.C. following $\$ 2000 \mathrm{e}$ (1976).

147. 423 F. Supp. 507 (W.D. Pa. 1976).

148. Id. at 509. 
executive order or its accompanying regulations is a backpay order specifically mentioned, such relief was granted in Duquesne Light Co. as a sanction available to "effectuate the purposes of the Order." 149 The East Texas Motor Freight court in an effort to "effectuate the purposes of the Order" could properly have directed retroactive seniority relief against the union, an organization preventing contract compliance.

Finally, the court's statement that the executive order may not defy the congressional policy enunciated in Title VII that bona fide seniority systems are lawful is clearly without foundation. ${ }^{150}$ While it is true that Congress has declared that a bona fide seniority system shall be lawful, ${ }^{151}$ it has done so strictly within the confines of Title VII. Significantly, although section 703(j) provides that the Act does not require employers to grant "preferential treatment," 152 and, according to Senators Clark and Case, the Act is essentially colorblind, ${ }^{153}$ Congress in 1972 nevertheless approved the highly preferential Philadelphia Plan and rejected an amendment that would have banned discrimination. ${ }^{154}$ Although the East Texas Motor Freight court cited Youngstown in stating that the "Executive may not . . . [act] in defiance of [congressional] policy," 155 a more careful consideration of both Youngstown and the history of the executive order suggests that the relief requested in East Texas Motor Freight could be lawfully granted on the basis of either the outright approval or "benevolent acquiescence" of Congress. The East Texas Motor Freight decision did not discuss the cases that have declared the executive order a separate remedy from Title VII and the Act ${ }^{156}$ - most notably, those cases in the area of seniority rights. ${ }^{157}$ In unnecessarily narrowing the scope of Executive Order No. 11,246, the Fifth Circuit rejected an appropriate opportunity to afford relief against discrimination in seniority agreements where Title VII had been rendered ineffectual.

149. Id.

150. See text accompanying notes $93-102$ supra.

151. 42 U.S.C. § $2000 \mathrm{e}-2(\mathrm{~h})(1976)$.

152. Id. $\$ 2000 \mathrm{e}-2(\mathrm{j})$. Compare section $703(\mathrm{a})$, reprinted in part at note 101 supra, making preferential treatment illegal.

153. See 110 CoNG. REC. 7212 (1964).

154. See text accompanying notes 99-101 supra.

155. 564 F.2d at 185.

156. Although several cases discuss the interplay of Title VII and Executive Order No. 11,246, see, e.g., Contractors Ass'n of E. Pa. v. Secretary of Labor, 442 F.2d 159 (3d Cir.), cert. denied, 404 U.S. 854 (1971); Crown Zellerbach Corp. v. Marshall, 441 F. Supp. 1110 (E.D. La. 1977), the court did not cite, much less discuss, any of them.

157. See Contractors Ass'n of E. Pa. v. Secretary of Labor, 442 F.2d 159 (3d Cir.), cert. denied, 404 U.S. 854 (1971). 


\section{ConClusion}

While most discriminatory acts are particularly vulnerable to statutory prohibition, insidious discrimination that has its roots in chronologically distant practices is less easily relieved. Seniority agreements falling into the latter classification were apparently exempted from the requirements of Title VII. However, in approving liberal readings of the remedial authority of Executive Order No. 11,246, Congress invited such "measures on individual presidential responsibility" which might serve to eliminate discrimination created by ostensibly neutral seniority provisions. At the very least, Congress has acquiesced in a policy derived either from "independent" executive authority or from the presidential procurement authority. In allowing the executive to set a wide range of policies dealing with employment discrimination in federal contracts, Congress has no doubt recognized that a different set of rules must direct federal contractors and that there is ample economic and political justification for holding these employers to a stricter standard than that applied to those not doing business with the government. Since seniority agreements that are prima facie neutral can be severely discriminatory, the President should be able to grant retroactive seniority relief to deserving minority employees based upon the affirmative action clause in government contracts. If Congress subsequently voices disapproval of this remedy, then it would not only have clarified the presidential authority in this area, but would also have extinguished the acquiescence that gave support to the executive exercise of power. Until such disapproval is manifested, however, the courts should afford Executive Order No. 11,246 the broad measure of remedial authority to which it is entitled. 
